\title{
PENGEMBANGAN SISTEM PEMBAYARAN UNTUK DESA WISATA TRI EKA BUANA DENGAN ONLINE PAYMENT
}

\author{
I G P Fajar Pranadi Sudha \\ na, I Gde Agus Jaya Sadguna, I Gede Nyoman Suta Waisnawa, Ayu Dwi \\ Yulianthi, A A Ayu Ngurah Harmini
}

1-5Politeknik Negeri Bali

${ }^{1}$ E-mail address fpranadi@pnb.ac.id; 2 E-mail address ; jayasadguna@pnb.ac.id;3 E-mail address ; sutawaisnawa@pnb.ac.id ; 4 E-mail address dwiyulianthi@pnb.ac.id; 5 E-mail address_gunghar@pnb.ac.id

\begin{abstract}
Since 2019, Tri Eka Buana Village, located in Sidemen sub-district, Karangasem Bali Regency, through the Bali State Polytechnic service team has received a PPDM grant to form a tourism village with natural potential and a producer of traditional Balinese arak drinks. Various kinds of activities from the solutions offered have been implemented in the first year of 2019. including compiling a master plan for developing a tourism village, formulating a village cleanliness supervision system, carrying out socialization of tourism village spatial planning, socialization and tourism outreach, and compiling a tourism village marketing program through digital marketing. One of the activities that has been carried out is the development of the Tri Eka Buana Tourism Village website. Online transactions are increasingly in demand, even have become a trend among the wider community. Besides, it can be done anytime and anywhere without any time or distance restrictions. Epayment offers various kinds of convenience and practicality in making payments. Various kinds of payment methods can be integrated into the system making it easier for customers to make payments according to orders made. The tourism village of Tri Eka Buana Sidemen Karangasem Bali, can take advantage of this online payment system to help tourism village operations in the future. The development of this online payment system can be developed by building a tourism village website, adding ecommerce facilities to the website that has been built, registering and activating one of the payment gateway services, and integrating the Tri Eka Buana tourism village website with a payment gateway service.
\end{abstract}

Keywords: online payment,tourist village

Abstrak
Sejak tahun 2019, Desa Tri Eka Buana yang terletak di kecamatan Sidemen,
Kabupaten Karangasem Bali, melalui tim pengabdian Politeknik Negeri
Bali telah mendapatkan hibah PPDM untuk membentuk desa wisata
dengan potensi alam dan penghasil minuman tradisional arak bali.


Berbagai macam kegiatan dari solusi yang ditawarkan telah dilaksanakan pada tahun I di 2019. meliputi menyusun Master Plan pengembangan desa wisata, merumuskan sistem pengawasan kebersihan desa, melaksanakan sosialisasi tata ruang desa wisata, sosialisasi dan penyuluhan kepariwisataan, dan menyusun program pemasaran Desa Wisata melalui digital marketing. Salah satu kegiatan yang telah terlaksana adalah pengambangan website Desa Wisata Tri Eka Buana.Transaksi online semakin diminati, bahkan sudah menjadi tren di kalangan masyarakat luas. Selain dapat dilakukan kapanpun dan dimanapun tanpa ada batasan waktu atau jarak. E-payment menawarkan berbagai macam kemudahan dan kepraktisan dalam melakukan pembayaran. Berbagai macam metode pembayaran dapat diintegrasikan kedalam sistem sehingga memudahkan pelanggan yang akan melakukan pembayaran sesuai pemesanan yang dilakukan. Desa wisata Tri Eka Buana Sidemen Karangasem Bali dapat memanfaatkan sistem payment online ini guna membantu oprasional desa wisata kedepannya. Pengembangan sistem online payment ini dapat dikembangkan dengan membangun website desa wisata, menambahkan fasilitas ecommerce ke dalam website yang telah dibangun, melakukan registrasi dan aktivasi ke salah satu layanan payment gateway, dan mengintegrasi website desa wisata Tri Eka Buana dengan layanan payment gateway.

Kata Kunci: pembayaran online, desa wisata, ecommerce

\section{PENDAHULUAN}

Salah satu pendekatan pengembangan wisata alternatif adalah desa wisata untuk pembangunan pedesaan yang berkelanjutan dalam bidang pariwisata (Zakaria, 2014) . Desa wisata merupakan suatu bentuk integrasi antara atraksi, akomodasi, dan fasilitas pendukung yang disajikan dalam suatu struktur kehidupan masyarakat yang menyatu dengan tata cara dan tradisi yang berlaku. Suatu desa wisata memiliki daya tarik yang khas (dapat berupa keunikan fisik lingkungan alam perdesaan, maupun kehidupan sosial budaya masyarakatnya) yang dikemas secara alami dan menarik sehingga daya tarik perdesaan dapat menggerakkan kunjungan wisatawan ke desa tersebut (Kementerian Kebudayaan dan Pariwisata, 2011: 1) Lebih jauh, pengembangan desa wisata bertujuan untuk meningkatkan kualitas hidup dengan menciptakan kondisi yang lebih baik untuk pertumbuhan ekonomi, penciptaan lapangan kerja, dan membantu pemerintah daerah dalam meningkatkan penyediaan pelayanan bagi warganya (Munir \& Fitanto, 2008).

Sebagai salah satu sumber pendapatan asli daerah, industri pariwisata perlu dikelola dengan baik. Salah satunya dengan mengintegrasikan penggunaan teknologi informasi dan 
komunikasi (TIK) di sektor pariwisata sebagai media promosi, media transaksi maupun media komunikasi dengan stakeholder. TIK telah berkembang menjadi salah satu pendukung industri pariwisata (Law et al., 2009; Bethapudi, 2013; Hanif et al., 2013). Dalam beberapa hal, TIK telah memberikan banyak perubahan serta menciptakan peluang-peluang baru bagi kemajuan dan perkembangan industri pariwisata, seperti untuk pemasaran, publikasi, promosi obyek dan atraksi wisata menggunakan website (Eraqi \& Abd-Alla, 2012).

Pembangunan Desa Wisata baru khususnya di Bali bertujuan untuk meratakan destinasi wisata di semua daerah tanpa harus terpusat di Bali Selatan dan Tenggara. Wisatawan yang datang setiap tahunnya selalu dalam jumlah yang fantastis dan harus menjadi pemacu untuk mengembangkan sektor pariwisata di Bali. Jika hanya terpusat di satu wilayah nantinya kondisinya akan terlalu sesak dan mengurangi kenyamanan wisatawan itu sendiri. Salah satu daerah di Bali yang perlu mendapat perhatian untuk mengembangkan desa wisatanya adalah Kabupaten Karangasem. Saat ini Kabupaten Karangasem telah memiliki total 20 desa wisata, namun 10 diantaranya sudah tidak aktif. Banyak desa di Karangasem berpotensi sebagai desa wisata namun masih banyak yang belum mampu mengelolanya sendiri, masih memerlukan bimbingan dan arahan dari berbagai pihak.

Politeknik Negeri Bali (PNB) yang lebih dikenal dengan nama "Poltek Bali" merupakan lembaga pendidikan tinggi bidang vokasi yang salah satu misinya adalah "Membangun keunggulan lembaga yang berorientasi kepariwisataan" (http://www.pnb.ac.id). Berkaitan dengan hal tersebut, PNB telah merumuskan COT (Center of Technology) Green Tourism yang dilandasi oleh konsep Tri Hita Karana yaitu Local Value yang mengutamakan Balancing antara Green Ethnic, Green Business dan Green Activities.

Sejak tahun 2019, Desa Tri Eka Buana yang terletak di kecamatan Sidemen, Kabupaten Karangasem Bali, melalui tim pengabdian Politeknik Negeri Bali telah mendapatkan hibah PPDM untuk membentuk desa wisata dengan potensi alam dan penghasil minuman tradisional arak bali. Berbagai macam kegiatan dari solusi yang ditawarkan telah dilaksanakan pada tahun I di 2019. meliputi menyusun Master Plan pengembangan desa wisata, merumuskan sistem pengawasan kebersihan desa, melaksanakan sosialisasi tata ruang desa wisata, 
sosialisasi dan penyuluhan kepariwisataan, dan menyusun program pemasaran Desa Wisata melalui digital marketing. Salah satu kegiatan yang telah terlaksana adalah pengambangan website Desa Wisata Tri Eka Buana.

Transaksi online semakin diminati, bahkan sudah menjadi tren di kalangan masyarakat luas. Selain dapat dilakukan kapanpun dan dimanapun tanpa ada batasan waktu atau jarak, belanja online juga dapat memberikan manfaat ekonomis. Semakin berkembangnya ecommerce, semakin beragam pula metode pembayaran yang biasa digunakan untuk melakukan transaksi. semakin beragamnya alternatif metode pembayaran dewasa ini. Masyarakat semakin mengenal metode pembayaran tidak hanya melalui transfer bank, sistem mencicil dari kartu kredit, atau cash on delivery, tapi juga metode pembayaran via mobile wallet atau aplikasi mobile sejenis lainnya.

Pembayaran digital dengan menggunakan uang elektronik mungkin hanyalah salah satu cara dalam menerima uang atau melakukan transaksi. Kendati demikian, karena kepraktisan, kemudahan, dan kecepatannya, pembayaran digital melalui teknologi mobile dengan menggunakan sistem berbasis server semakin banyak diadopsi konsumen.
Perkembangan teknologi mobile juga turut mendorong tren e-payment ini. Tak heran pengembang dan penyedia layanan pun menjadikannya sebagai salah satu unit bisnis utama mereka. Para penyedia layanan pun semakin menyempurnakan fitur kemudahan/ kenyamanan dalam bertransaksi, sekaligus faktor keamanannya.

Melihat kemajuan teknologi informasi dan mulai tumbuhnya desa wisata baru di berbagai daerah, maka perlu dikembangkan sebuah sistem pembayaran untuk desa wisata untuk memudahkan pengelolaan pembayaran ke desa wisata dengan memanfaatkan berbagai alternatif cara pembayaran yang berkembang pesat akhir-akhir ini.

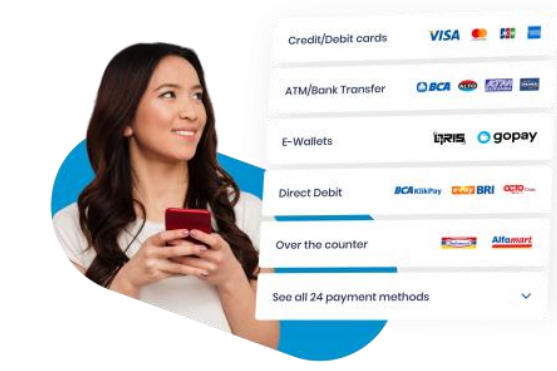

Gambar 1 Berbagai Metode pembayaran yang disediakan melalui online payment.

\section{METODE DAN PELAKSANAAN}

Metode yang dipakai untuk membangun sistem pembayaran online desa wisata Tri Eka Buana adalah sebagai berikut:

a. Membangun website desa wisata yang dapat menampilkan dan 
mempromosikan potensi desa wisata secara digital

b. Menambahkan fasilitas ecommerce ke dalam website yang telah dibangun guna melakukan integrase dengan layanan payment gateway.

c. Melakukan registrasi dan aktivasi ke salah satu layanan payment gateway yang menyediakan berbagai jalur pembayaran yang ada.

d. Melakukan integrasi website desa wisata Tri Eka Buana dengan layanan payment gateway yang telah di aktivasi pada tahap sebelumnya.

e. Melakukan uji dan testing terhadap sistem yang telah dibangun pada tahap sebelumnya.

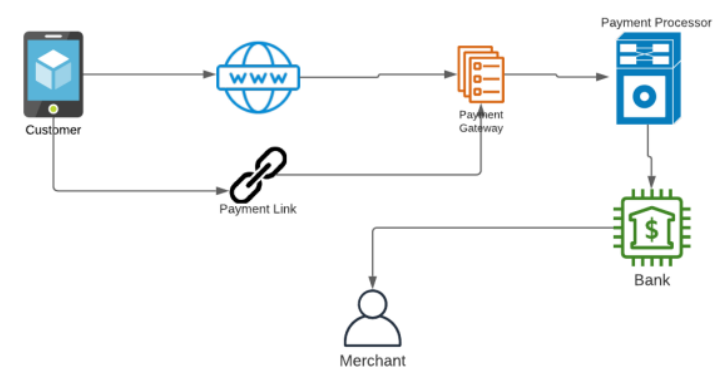

Gambar 1 Gambaran Sistem Pembayaran Online Desa Wisata Tri Eka Buana

\section{Pelaksanaan Kegiatan}

Implementasi dari sistem pembayaran online ini di bangun didalam website desa tri eka buana yang dapat di akses pasda alamat: https://desatriekabuana.com. Website dibangun dengan platform wordpress dan plugin woocommerce sebagai plugins ecommerce nya.

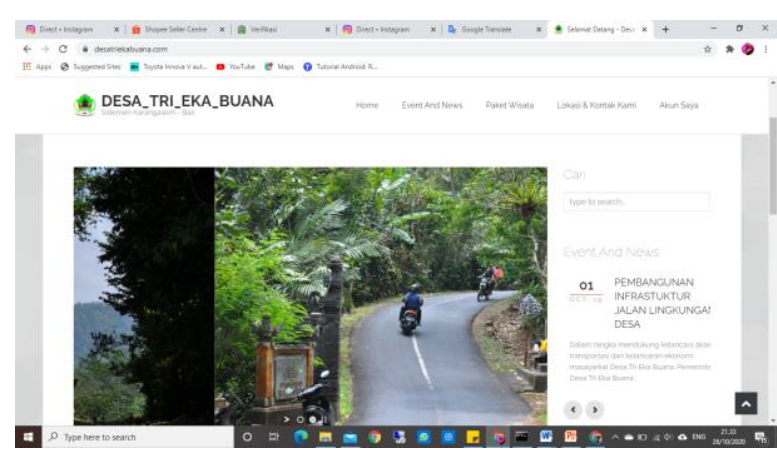

Gambar 3 Website Desa Tri Eka Buana.

Payment Gateway yang digunakan adalah midtrans dikarenakan saat ini memiliki metode pembayaran terlengkap dari beberapa layanan payment gateway yang ada.

\section{HASIL DAN PEMBAHASAN}

Hasil dari sistem pembayaran online yang mengintegrasikan website dengan layanan payment gateway telah dapat melakukan pembayaran dengan berbagai macam jenis pembayaran baik kartu kredit, kartu debit, e-wallet, bahkan melalui indomaret. Selain melalui website sistem pembayaran online ini juga dapat membuat payment link yang dapat dibagikan ke aplikasi instant messaging ataupun media social kepada customer. 

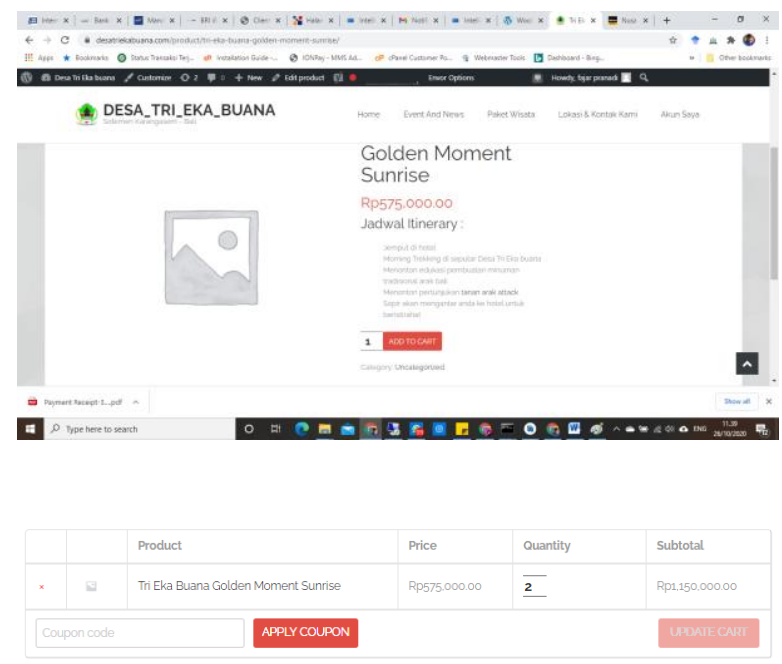

Cart Totals

Gambar 4 Transaksi melalui website

Pada website fasilitas e-commerce akan melakukan rekap terhadap transaksi yang telah dibuat, untuk kemudian dilakukan checkout dengan memilih metode pembayaran yang akan digunakan.

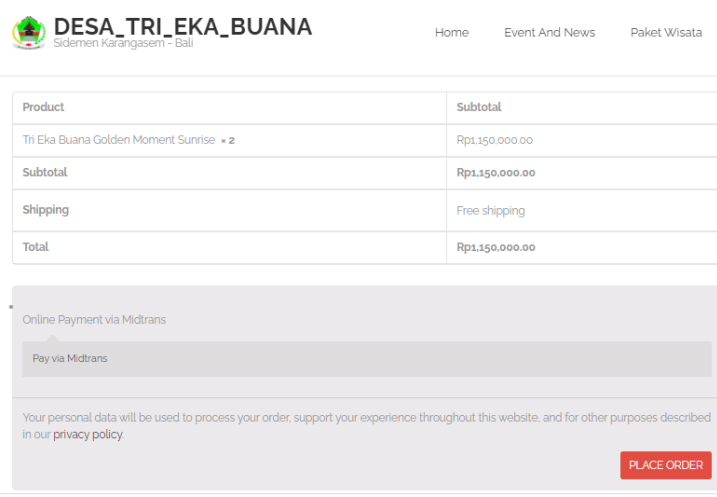

Gambar 5 Proses checkout transaksi

Setelah melakukan checkout, sistem akan secara otomatis melakukan redirect ke halaman payment gateway dengan berbagai pilihan jenis pembayaran dengan tingkat keamanan yang telah di sediakan oleh layanan paymet gateway.
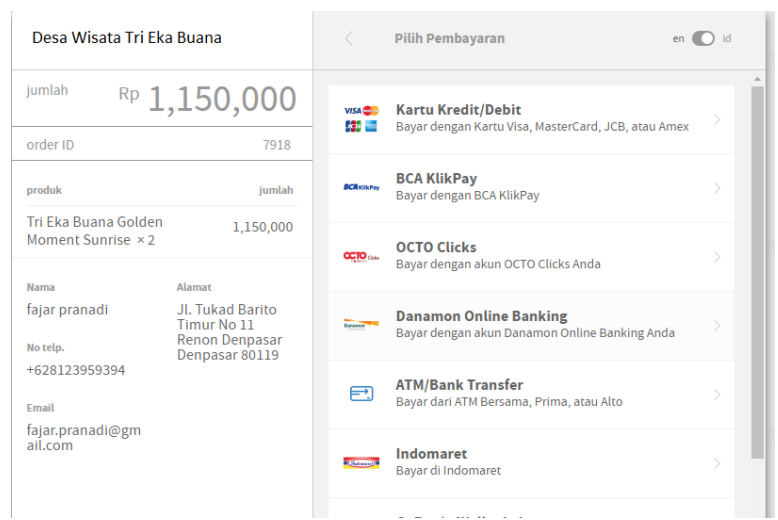

Gambar 6 Pilihan jenis metode pembayaran yang bisa diterima

Pilihan menggunakan QRIS yang merupakan QR Code standard Indonesia dapat di gunakan pada sistem pembayaran ini. Berbagai layanan QR code yang berbasis QRIS dapat diterima melalui sistem ini.

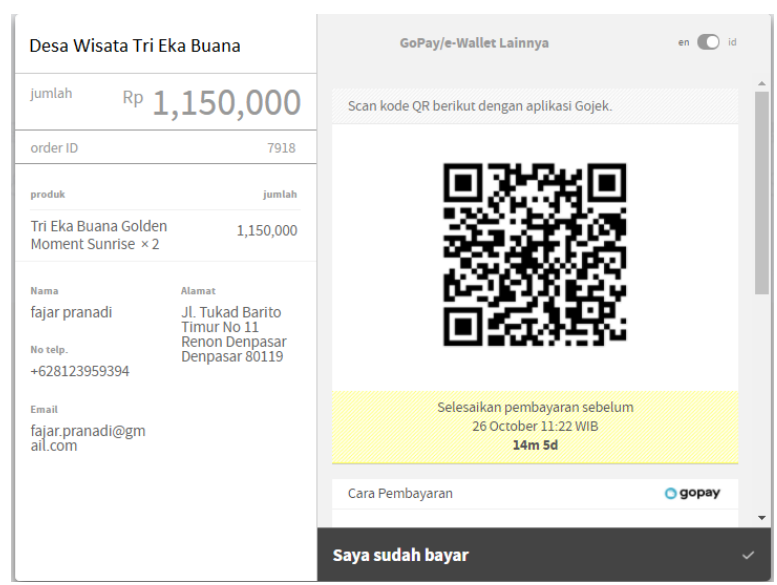

Gambar 7 Pilihan pembayaran melalui QRIS

Selain melalui website sistem pembayaran ini juga dapat membuat payment link yang dapat dibagikan langsung melalui aplikasi instant messaging ataupun media sosial kepada 
customer Contoh payment link yang dihasilkan adalah sebagai berikut : "https://app.sandbox.midtrans.com/pay ment-links/1603685740468 “

Apabila payment link ini di klik maka customer akan langsung di redirect ke halaman yang sama seperti melalui website seperti terlihat pada gambar $8 \mathrm{di}$ bawah ini.

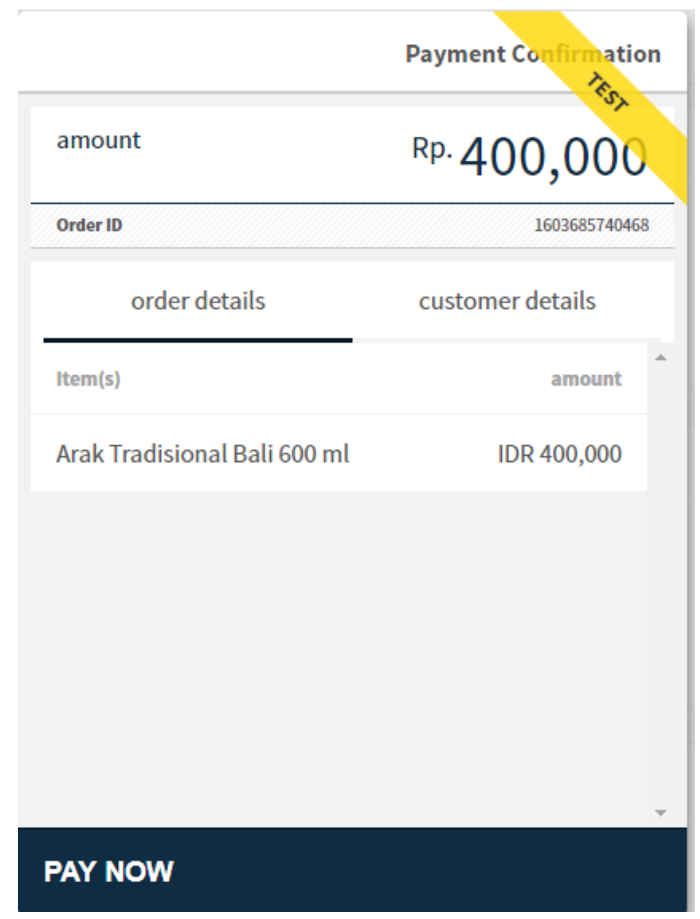

Gambar 8 hasil redirect dari payment link

Semua transaksi yang telah dilakukan akan di settlement ke rekening Bank milik Desa Tri eka Buana pada $\mathrm{H}+1$ atau keesokan harinya.

\section{PENUTUP}

\section{Simpulan}

E-payment menawarkan berbagai macam kemudahan dan kepraktisan dalam melakukan pembayaran. Berbagai macam metode pembayaran dapat diintegrasikan kedalam sistem sehingga memudahkan pelanggan yang akan melakukan pembayaran sesuai pemesanan yang dilakukan. Desa wisata Tri Eka Buana Sidemen Karangasem Bali yang menawarkan berbagi potensi alam dan produksi minuman tradisional arak bali dapat memanfaatkan sistem payment online ini guna membantu oprasional desa wisata kedepannya.

Pengembangan sistem online payment ini dapat dikembangkan dengan membangun website desa wisata, menambahkan fasilitas ecommerce ke dalam website yang telah dibangun, melakukan registrasi dan aktivasi ke salah satu layanan payment gateway, dan mengintegrasi website desa wisata Tri Eka Buana dengan layanan payment gateway.

\section{DAFTAR PUSTAKA}

Bethapudi, A. (2013). The Role of ICT in Tourism Industry. Journal of Applied Economics and Business, 1(4): $67-79$.

Eraqi, M., \& Abd-Alla, G. (2008). Information Systems and Tourism Marketing: New Challenges for Tourism Business Sector in Egypt. Information Technology in Hospitality, 5: 1 - 14.

Hanif, M. I., Yunfei, S., Xiu-Yin, B., Hanif, M.S., \& Shareef, M.T. (2013). 
The Efficiency of Innovative Marketing Information System: An Empirical Study of Tourism Industry of Pakistan. International Review of Management and Business Research, 1(4): 1042 1056.

Law, Leung, \& Buhalis, D. (2009). Information Technology Applications in Hospitality and Tourism: A Review Of Publications From 2005 TO 2007. Journal of Travel \& Tourism Marketing, 26(5): 599 - 612.

Munir, R., \& Fitanto, B. (2005). Pengembangan ekonomi lokal partisipatif: Masalah, kebijakan, dan panduan pelaksanaan kegiatan.
Jakarta: Local Governance Support Program, USAID.

Zakaria, Faris. \& Suprihardjo, Rima Dewi. 2014. Konsep Pengembangan Kawasan Desa Wisata di Desa Bandungan Kecamatan Pakong Kabupaten Pamekasan. Jurnal Teknik POMITS, Vol 3 No 2: C245C249

Politeknik Negeri Bali. . Misi Politeknik Negeri Bali, [online](http://www.pnb.ac.id , diakses pada 19 agustus 2018) 